\title{
Cell Device
}

National Cancer Institute

\section{Source}

National Cancer Institute. Cell Device. NCI Thesaurus. Code C49867.

A device that is designed as a removable and replaceable part of another device. 